\title{
WORD ORDER ALIGNMENT IN THREE-ARGUMENT CONSTRUCTIONS OF IRISH
}

\begin{abstract}
A b stract. This study examines the ordering of the actor (A), theme (T) and recipient (R) arguments in three-argument clauses, the prepositional ditransitive constructions of Irish. The ordering of the $\mathrm{A}, \mathrm{T}$ and $\mathrm{R}$ arguments in three-argument clauses is an area where linguistic complexity is manifest in the Irish grammar. Across languages, the factors which influence word order adjustments, from a basic word order of A-T-R, are known to include iconicity, information structure and topicalisation, the distinction between given and new information, the effects of the various referential hierarchies, and syntactic weight. We show that some, but not all, of these apply to the Irish data. Under certain conditions, the word order of these Irish three-argument clauses changes in a different alignment. Specifically, if the $\mathrm{T}$ is an accusative pronoun then the word order alignment changes and consequently the $\mathrm{T}$ occurs after the $\mathrm{R}$ in clause final position, yielding an A-R-T word order. We argue that post-positioning of the theme PN is due to the alignment effects that can be explained by reference to the nominal and person hierarchies, and their intersection with the principle of syntactic weight. The Irish grammar seems to be disposed to place the accusative object PN T in clause final position in word order, adding an imposed salience. We characterise the effects of the nominal and person hierarchies, and syntactic weight, on word order within these constructions. We use elements of the functional model of Role and Reference Grammar in this characterisation. These word alignment effects raise important questions of the distribution of linguistic complexity across the grammar of Irish, and the interfaces between semantics, and syntax, as well as information structure.
\end{abstract}

Keywords: Irish ditransitive; word order; nominal and person hierarchies; syntactic weight; postpositioned theme.

BRIAN NOLAN, PhD, Technological University Dublin, Blanchardstown Campus; e-mail: brian.nolan@gmail.com; ORCID: https://orcid.org/0000-0002-2017-6543. 


\section{INTRODUCTION}

The argument realisation and subsequent word ordering of the actor (A), theme $(\mathrm{T})$ and recipient $(\mathrm{R})$ arguments in three-argument clauses, the prepositional ditransitive constructions of Irish are examined in this paper. Under certain conditions, the word order of these clauses changes in interesting ways. The factors which influence word order adjustments, from a basic word order of A-T-R, within a language are known to include iconicity, information structure and topicalisation, the distinction between given and new information, the effects of the various referential hierarchies, and syntactic weight. The Irish prepositional ditransitive constructions require three arguments (Nolan). If the $\mathrm{T}$ argument is an $\mathrm{N}$, then it occurs immediately after the grammatical "subject" in the syntax as an object within the construction. What is interesting here is that if the T object is an accusative PN, then the word order alignment changes and the pronominal theme occurs in a completely different word order position, after the $\mathrm{R}$, in clause final position. The post-positioning of the pronominal theme occurs irrespective of which ditransitive verb is used.

Despite the complexity and difficulty in accounting for this postposing phenomenon of Irish, there have been surprisingly few treatments of it. In one account, Bennett et al. ("Pronouns") and Bennett et al. ("Lightest to the Right") take a view of the PN postposing of Irish that is motivated by prosodic considerations, and they argue that syntax and phonology intersect to determine the ordering for the elements that make up a sentence. Their account is motivated by prosody and prosodic considerations in the main. The paper by Bennet et al. argue that this PN postposing is a phonological process due to prosody, and they construct an exclusively phonological treatment of the phenomenon that involves no reference to syntactic theory. In their account, information structure properties play no role. A completely different and contrasting view is taken by Mulkern (197), who argues instead for an account of PN postposing of Irish based on the information structure considerations that Bennett et al. dismiss. She argues that postposing signals how the speaker wishes to present the information which the utterance expresses, such that a boundary is marked between two parts of the information structure. In Mulkern's account, the first part (preceding the PN) is the assertion, which expresses information that the speaker presents as new while the second part (following the PN) is the presupposition which expresses given information. It is worth noting that, as this postposing of the T PN 
occurs not just in spoken language (where aural prosodic cues are available), but also in written language (where prosodic cues are not available) and digital internet memes, it seems that other factors might be at play in the grammar with respect to this phenomenon. We argue that this postpositioning of the accusative object $\mathrm{PN}$ theme is, in fact, due to alignment effects that can be explained by reference to the nominal and person hierarchies, and their intersection with the principle of syntactic weight (Siewierska, "Syntactic Weight," "Word Order," "Person Agreement," Person; Haspelmath, "Argument Marking," "Ditransitive Constructions"). The ordering of the A, $\mathrm{T}$ and $\mathrm{R}$ arguments in three-argument clauses, resulting from how these arguments intersect with the nominal and person hierarchies, and syntactic weight, is an area of syntactic complexity in Irish grammar.

This chapter has the following organisation. In section 2 following, we introduce the data and examine the factors that are known to influence word order in the clause. In section 3, we look briefly at the typological perspective on how the A-T-R vs. A-R-T alignment occurs cross-linguistically for three-argument constructions. In section 4 , we examine the data introduced in section 2, the three-argument constructions of Irish. In section 5, we provide a concluding summary discussion.

\section{INFLUENCING WORD ORDER IN THE CLAUSE}

In Irish, the three-argument constructions only allow a felicitous form that has the recipient $\mathrm{R}$ flagged by a preposition (1). This data presents the clear occurrence patterns in syntax (2).

$\begin{array}{llll}\text { (1) a. Thug Aodh Rua a chaisleán } & \text { do Mhaolmhuire. } \\ \text { give.PST Hugh Red his castle } & \text { to Maolmhuire } \\ \text { Actor } & \text { Theme } & \text { Recipient }\end{array}$

'Red Hugh gave his castle to Maolmhuire.'

b. Thug Lorcán an leabhar dom.

give.PST Lorcan DET book to $+1 \mathrm{SG}$

Actor Theme Recipient

'Lorcan gave the book to me.' 
c. Chuir sé tú in aithne di.

put.PST 3SG.M 2SG in recognition to +3 SG.F

\section{Actor Theme Recipient}

'He introduced you to her.'

d. Bhain sé fainne óir dá mhéar agus thug do Bhean Fhostair é.

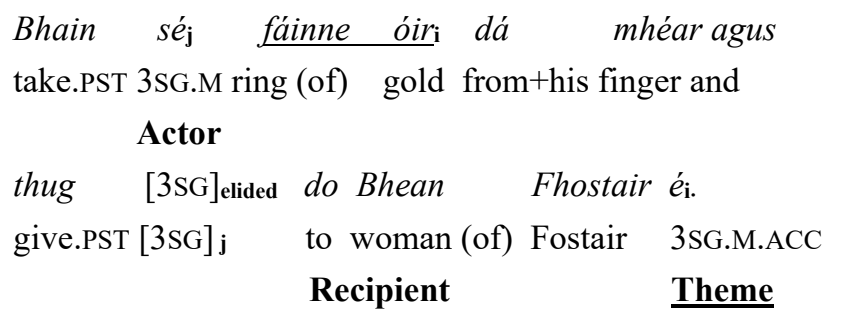

'He took a ring of gold from his finger and gave it to Foster's wife.'
e. Thug Lorcán dom é
give.PST Lorcan to $+1 \mathrm{SG}$ 3SG.M.ACC
Actor Recipient Theme

LIT: 'Lorcan gave to me it'

'Lorcan gave it to me.'

(2) The patterns of occurrence of the three-argument constructions of Irish:
a. $\quad\left[\mathrm{V} \mathrm{NP}{ }^{\mathrm{A}} \mathrm{NP}^{\mathrm{T}}[\mathrm{P} \mathrm{NP}]^{\mathrm{R}}\right] \quad$ : $\quad$ A-T-R
b. $\left[\mathrm{VNP}^{\mathbf{A}} \mathrm{NP}^{\mathrm{T}} \mathrm{PPN}^{\mathrm{R}}\right] \quad$ : A-T-R
c. $\left[\mathrm{V} \mathrm{NP}{ }^{\mathbf{A}} \mathrm{PN}^{\mathbf{T}} \mathrm{PPN}^{\mathrm{R}}\right] \quad$ : $\mathrm{A}-\mathrm{T}-\mathrm{R}$
d. $\quad\left[\mathrm{V} \mathrm{NP}{ }^{\mathrm{A}}[\mathrm{P} \mathrm{NP}]^{\mathrm{R}}\right.$ 3.PN $\left.{ }^{\mathrm{T}}\right] \quad$ : $\quad$ A-R-T marked form of construction
e. $\left[\mathrm{V} \mathrm{NPA} \mathrm{PPN}^{\mathrm{R}}\right.$ 3.PN $\left.\mathrm{PN}^{\mathrm{T}}\right] \quad$ : A-R-T marked form of construction

The question then is: What are the actual factors that influence the word order variation in the realisation of these arguments in the context of Irish? Cross linguistically, the factors that are considered to influence word order include iconic word order sequencing (Payne, The Pragmatics, Pragmatics, "Verb Initial Languages"), syntactic weight, the informational status of referents, and the various referential hierarchies. We briefly discuss each of these factors and their relevance to word order alignment on the constructions under discussion, and we will see that some, but not all, are applicable.

There is a claim that might be made in respect of $\mathrm{V}$-initial languages to the effect that they are iconic in reflecting temporal sequencing, whereby the 
realisation of the event denoted by the verb and its arguments reflect the logical structure of an event. Malchukov et al. (Ditransitive Constructions 12, Studies 17) note that the order T-R is more iconic than the order R-T, because, in the unfolding of the event, the $T$ is first involved in the action, which reaches the $\mathrm{R}$ only in a second step. However, this order cannot be motivated by universal parsing considerations, as it is clear that VSO languages are in a minority within the world's languages. The frequency of VSO languages with respect to the other word orders is identified in (3) as around $10 \%$. Iconicity is, therefore, unlikely to be a major factor in word order cross linguistically, and cannot realistically be claimed for Irish.

(3) Basic word order frequencies

\begin{tabular}{|lcc|c|cccc} 
& $\begin{array}{c}\text { SOV } \\
\mathbf{\%}\end{array}$ & $\begin{array}{c}\text { SVO } \\
\mathbf{\%}\end{array}$ & $\begin{array}{c}\text { VSO } \\
\mathbf{\%}\end{array}$ & $\begin{array}{c}\text { VOS } \\
\mathbf{\%}\end{array}$ & $\begin{array}{c}\text { OVS } \\
\mathbf{\%}\end{array}$ & $\begin{array}{c}\text { OSV } \\
\mathbf{\%}\end{array}$ & $\begin{array}{c}\text { Not } \\
\text { classified }\end{array}$ \\
Ruhlen & 51.5 & 35.6 & $\mathbf{1 0 . 5}$ & 2.1 & 0 & 0.2 & - \\
Mallinson and Blake & 41 & 35 & $\mathbf{9}$ & 2 & 1 & 1 & 11
\end{tabular}

The principle of syntactic weight maintains that constituents in a clause will occur in an order of increasing weight and that this is an underlying determinant of word order (Hawkins, Performance Theory 214-242, Efficiency $122 \mathrm{ff}$.). The weight principle states that the syntactic weight of the components in a phrasal unit of a sentence determines their positional distribution with shorter and lighter constituents before longer and heavier ones. Syntactic weight is typically understood as the number of words in a phrase, or number of nodes (broadly construed in some linguistic paradigm), phonological complexity or number of syllables in a constituent. Additionally, the complexity of the word or phrasal unit counts towards weight. Indeed, the weight principle is assumed by its proponents to be a universal principle of word order and information structure, often measured as (i) the count of the number of words or syllables, and (ii) the morphosyntactic complexity of these clausal constituents (Siewierska, "Word Order"). Longer and more complex constituents in English, for example, are placed at the end of a clause, giving a heavier sentence end-weight. A key principle for Hawkins is the Principle of Early Immediate Constituents (EIC). Hawkins argues that syntactic weight is decisive in understanding word order variation. Specifically, Hawkins claims that constituents are found to occur in certain word orders so that syntactic constituents can be recognised and processed quickly and efficiently. Hawkins (Efficiency 7) argues that the Greenberg word order correlations point to a prin- 
ciple of efficient parsing, whose preferences appear to be conventionalised in grammars. The grammar will attempt to place the heaviest constituent elements last in the clause.

Overall, then, word-ordering strategies are employed by the language user, within a language community, in order to reduce complexity and to facilitate ease of production and comprehension with other members of that community. Recognising this, in a clause, the constituents are organised around some measure of salience or accessibility to the hearer and speaker, that is, according to information structure considerations, such that given, old and previously mentioned, information is delivered before new, not yet mentioned, information (Birner; Birner and Ward; Brown; Stefanowitsch and Gries). Old and given information already introduced into the discourse are referred to by shorter elements, typically anaphoric pronouns. Given elements are lighter. Heavy constituents are more likely to contain new information. We summarise the preference for given before new in (4).

(4) The preference for given before new

\begin{tabular}{lll}
\multicolumn{1}{c}{ Constituent } & Characteristics & Earlier / Later \\
\hline HEAVY constituent: & NEW information & LATER in the clause \\
LIGHT constituent: & OLD, given, typically realised as a PN & EARLIER \\
\hline
\end{tabular}

The preference for given before new is a major ordering principle in language. The consequence of this is that this kind of information structuring is assumed to influence the organisation of clauses in some principled way and, as such, to have an impact on word order.

Given information is that which we consider to have been mentioned already, residing in discourse common ground, and may therefore be taken for granted. We expect a sentence to begin with given information, whereas new information occurs at the end of a clause. New information refers to the unknown part of a message and is information the speaker assumes the hearer to be unaware of. New referents typically need some extra linguistic content to ensure they are identifiable to the hearer in the discourse, thereby making these new elements heavier. In other words, the topic with given information is the initial part of a sentence and the new information, the focus of the message, normally occurs at the end of the clause. This is related to the application of the principles of end-focus and end-weight by the speaker. Sentence end-focus implies that the new, or most important idea in a piece of information, should be placed towards the end. 
New information is heavier and the tendency is to place the more complex heavier elements at the end of a sentence. Therefore, the principle of syntactic end-weight may lead to word order adjustments, when combined with information structure status. Importantly, too, in the absence of difference in information status, differences in syntactic weight are suggested to most strongly affect word order. The term FOCUS is used to refer to the highlighting of parts of a sentence for communicative purposes such that one constituent of the clause is moved to a place where it has the greatest communicative impact. In written language, the only way to achieve focus is to re-arrange the word order of the constituents within the clause.

The referential hierarchy set ranges over nominals, person, animacy, gender, definiteness, and the thematic roles (5). Heine and König (94) note that languages differ considerably in the way and extent to which the domains listed are treated in the grammar, and how the domains interact. In some languages, animacy may be the primary domain, while in others (especially in discourse configurational languages) it is referentiality.

On the nominal hierarchy [Nominal hierarchy: PRONOUN $>$ PROPER NOUN $>$ COMMON NOUN], pronouns are more prominent than lexical Ns i.e., $1 \mathrm{ST} / 2 \mathrm{ND}>3 \mathrm{RD}>$ PROPER NOUN $>$ HUMAN $>$ NON-HUMAN (Silverstein), and [Person hierarchy] 1 st and 2 nd persons are more prominent than $3 \mathrm{rd}$ persons. Person has been highly correlated with various properties; for example, pronouns are: short, definite, and given, and 1st and 2nd person pronouns are animate. The animacy of referents is an important factor in the organisation of word order and this is recognised as the "animacy hierarchy" (Croft 111-17). In this regard, human and animate referents precede inanimate entities in linear word order. Generally, animacy-based ordering preferences can be viewed as part of our more general cognitive accessibility apparatus whereby humans find other humans (and animates) to be highly salient.

(5) The referential and thematic hierarchies:
a) Nominal
pronoun $>$ proper noun $>$ common noun (HUMAN $>$ NON-HUMAN)
b) Person
first $>$ second $>$ third
c) Animacy
human $>$ animate $>$ inanimate
d) Gender
male $>$ female $>$ neuter
e) Definiteness definite $>$ referential $>$ non-referential
f) Thematic
Agent $>$ Effector $>$ Experiencer $>$ Location/Recipient $>$ Theme $>$ Patient 
The thematic hierarchy is a much-debated area (Falk 33-34; Levin and Rappaport Hovav 162-63), and we assume the thematic hierarchy ranking, based on Van Valin (Exploring, "Role and Reference Grammar"), consisting of (AGENT $>$ EFFECTOR $>$ EXPERIENCER $>$ LOCATION/RECIPIENT $>$ THEME $>$ PATIENT). From the perspective of Role and Reference Grammar (RRG), a functional model, the linking system between syntax and semantics correctly links the agent to grammatical "subject," theme to direct object and recipient to indirect object. It has been found across languages that agents and recipients are typically human, while patients and themes often are not.

RRG is a model of grammar that posits a direct mapping between the semantic representation of a sentence and its syntactic representation (Nolan; Van Valin, Exploring). RRG is a mono strata-theory, positing only one level of syntactic representation, the actual form of the sentence and its linking algorithm can work in both directions from syntactic representation to semantic representation, or vice versa. In RRG, semantic decomposition of predicates and their semantic argument structures are represented as logical structures. The lexicon in RRG takes the position that lexical entries for verbs should contain unique information only, with as much information as possible derived from general lexical rules. The main features of RRG include the use of lexical decomposition, based upon predicate semantics, an analysis of the layered structure of the clause structure and the use of a set of thematic roles organised into a hierarchy in which the highest-ranking roles are Actor (for the most active participant) and Undergoer. RRG characterises the relationship between syntax and semantics and can account for how semantic representations are mapped into syntactic representations via a bidirectional linking system. RRG also accounts for the very different process of mapping syntactic representations to semantic representations. Of the two directions, syntactic representation to semantic representation is the more difficult since it involves interpreting the morphosyntactic form of a sentence and inferring the semantic functions of the sentence from it.

As well as with the three-argument constructions, evidence of the clause final behaviour of a third person pronominal direct object is also found elsewhere within Irish grammar. Specifically, this occurs with topicalisation processes and the use and distribution of resumptive pronouns. A key difference between the word ordering found in three-argument constructions and the topicalisation processes is that, in the topicalisation processes, a resumptive pronoun is necessary in the clause if the element is a semantic argument of the clause proper and that its omission leads to ungrammaticality (Van 
Valin and LaPolla 36; Butler 171). In contrast, a resumptive pronoun is not required in the word order changes found with three-argument constructions, as these are motivated by different factors to the topicalisation processes discussed here.

According to Hickey (157ff.), the primary mechanism by which a speaker topicalises a discourse element in Modern Irish is via fronting, and this involves dislocation constructions. The dislocation constructions of Modern Irish support the topicalisation of information with pre- and post-posed information external to the clause but within the sentence. Extra-clausal leftfronted phrases involve the use of constructions in which a phrase to be fronted is placed before the matrix clause in the sentence. The relationship is characterised by the link between the fronted phrase and a pronoun in the matrix clause that uses the fronted extra-clausal phrase as its referential antecedent. Typically, the resumptive pronoun is clause final, and we indicate this with an index in the examples, as seen in (6), and it is maximally light as regards syntactic weight (O'Siadhail 212).

(6) An múinteoir $r_{1}$ óg, chonaic mé ar maidin é

An múinteoir ${ }_{1}$ óg, chonaic mé ar maidin é 1

DET teacher young see.PST 1 SG on morning 3SG.M.ACC

'The young teacher 1 , I saw him 1 this morning.'

The resumptive pronoun employed in these topicalisation constructions is a mandatory argument and has an anaphoric function even though it refers to an antecedent outside the primary clause, but within the sentence. Irish has a fixed word order that cannot be violated if the sentence is to be grammatical.

\section{TYPOLOGICAL PERSPECTIVES \\ ON THE THREE-ARGUMENT CONSTRUCTIONS}

Evidence of the cross-linguistic placement of the A-T-R arguments, in a functional-typological perspective, is found in Malchukov et al. (Ditransitive Constructions, Studies). They argue that the ordering of the theme (T) and the recipient $(\mathrm{R})$ with respect to each other is not random, and that some principles apply such that if both $T$ and $R$ arguments are unmarked, the $R$ generally precedes the theme giving a word order of A-R-T.

Interestingly for our discussion, Malchukov et al. argue that, based on an appeal to the primacy of the animacy hierarchy, the fact that the $\mathrm{R}$ is 
generally human and definite, and thus tends to be more topical than the T, which is typically inanimate and indefinite, there is an expectation that the $\mathrm{R}-\mathrm{T}$ order occurs overwhelmingly and that $\mathrm{T}-\mathrm{R}$ order is quite marginal. Additionally, Heine and König (102) claim that while "R arguments follow $\mathrm{T}$ while there is no single European language where heavy $\mathrm{R}$ precedes light T..., and also no language where heavy T precedes light R," as in (7), where we find a heavy $R$ and a light $T$ (8). With respect to syntactic weight effects, it has been claimed that this T-R order is favoured in SVO and VSO languages because of the Early Immediate Constituents principle (Hawkins, Performance Theory). This, however, as we will show in section 4, is not fully reflective of the situation that holds for Irish.

(7) a. * $\mathbf{R}_{\text {heavy }} \mathbf{T}_{\text {Light }} \quad$ - This does not reflect the Irish data

b. * $\mathbf{T}_{\text {HeAvY }} \mathbf{R}_{\text {Light }}$

(8) a. $\quad \mathbf{T}_{\mathrm{NP}}^{\text {HEAVY }} \mathbf{R}[\mathbf{P} \mathbf{N P}]^{\text {HEAVY }}$

b. $\mathbf{T}_{\mathrm{NP}}{ }^{\mathrm{HEAVY}} \mathbf{R P P N}^{\mathrm{HEAVY}}$

c. TPN ${ }^{\text {LIGHT }} \mathbf{R}_{\text {PpN }}{ }^{\text {HEANY }}$

d. $\quad \mathbf{R}[\mathbf{P} \text { NP }]^{\text {HEAVY }} \mathbf{T}_{\mathbf{P N}}{ }^{\text {LIGHT }}$ - This contradicts the claims of Primus

e. $\mathbf{R}_{\text {PPN }}{ }^{\text {HEAVY }} \quad \mathbf{T}_{\text {PN }}{ }^{\text {LIGHT }}$

In this paper we claim that:

a) This T-R marginality does not reflect the situation with the Irish threeargument constructions, as evidenced by the data in (1) and the occurrence patterns in (8).

b) When the $\mathrm{R}$ is flagged by an adposition, as we find in the Irish situation with the $\mathrm{R}$ argument, the T-R order is found to be the overwhelmingly dominant order in constructions (Primus; Heine and König).

c) The nominal and person hierarchies come into play with respect to Irish three-argument constructions.

d) The statement by Heine and König (102) that "there is no single European language where heavy $\mathrm{R}$ precedes light $\mathrm{T}$... and also no language where heavy $T$ precedes light $\mathrm{R}$ " does not reflect the situation found in the Irish data where we find a heavy $\mathrm{R}$ and a light $\mathrm{T}$.

e) The realisation of the $T$ and $R$ in the three-argument constructions goes against the claims of the Principle of Early Immediate Constituents. In Irish three-argument constructions, the lightest argument, the 3.PN T, is clause final with the pattern A-R-T. 


\section{THE THREE-ARGUMENT CONSTRUCTIONS OF IRISH}

In this section, we examine each of the examples introduced in (1), as representative of the phenomena under study. We examine each individually ${ }^{1}$ and discuss their important characteristics with respect to word order to show how the referential hierarchies and syntactic weight interact to determine the A-T-R vs. A-R-T alignment.

We start our discussion with the example in (9) which exhibits the syntactic

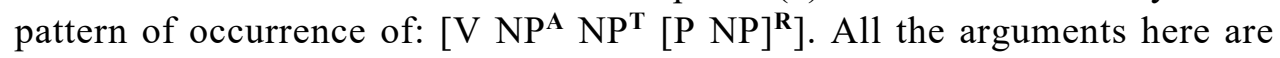
realised full lexical nominals. The third argument, which is embedded in a prepositional phrase as [ $d o: \mathrm{P}$ 'to' NP], is the recipient NP argument. The word order in this example is A-T-R. The T is a full lexical nominal and, as such, has a heavy syntactic weight. The $\mathrm{R}$ is also a full lexical nominal with a heavy syntactic weight. The syntactic weight of the final R ([P NP]) is high, irrespective of whether one counts words or syllables in the prepositional phrase containing the recipient.

\begin{tabular}{lllll}
\multicolumn{6}{c}{ Word order pattern a: $\left[\mathbf{V} \mathbf{N P}^{\mathbf{A}}\right.$} & $\left.\mathbf{N P}^{\mathbf{T}}[\mathbf{P} \mathbf{N P}]^{\mathbf{R}}\right]$ & $\rightarrow \mathbf{A}-\mathbf{T}-\mathbf{R}$ \\
(9) (=1a) & Thug & Aodh Rua & a chaisleán & do Mhaolmhuire. \\
give.PST & Red-Hugh & his castle & to Maolmhuire \\
& Actor & $\frac{\text { Theme }}{\mathbf{H 3 N}^{2}}$ & Recipient \\
& & H3N
\end{tabular}

'Red Hugh gave his castle to Maolmhuire.'

We next look at an example with the $\left[\mathrm{V} \mathrm{NP}{ }^{\mathbf{A}} \mathrm{NP}^{\mathrm{T}} \mathrm{PPN}^{\mathrm{R}}\right.$ ] syntactic pattern of occurrence (10). The $\mathrm{T}$ argument is realised as a full lexical nominal while the $\mathrm{R}$ is realised as the object of a preposition and conflated into a conjugating prepositional pronoun (PPN) to form the prepositional pronoun dom 'to+1SG'. The word order with the pronominal recipient is A-T-R. Here, the $\mathrm{R}$ is final. Both the $\mathrm{T}$ and $\mathrm{R}$ arguments are syntactically heavy, but the $\mathrm{R}$ is more complex given its status as a $\mathrm{PPN}^{3}$ than the full lexical nominal $\mathrm{T}$.

\footnotetext{
${ }^{1}$ We renumber each example for ease of reading, such that (1a) becomes (9), (1b) becomes (10), and so on.

${ }^{2}$ We use the notation of $\mathrm{H}=$ heavy, and $\mathrm{L}=$ light as in L2PN and H1PN, etc.

${ }^{3}$ The prepositions of Irish can morphologically conflate with personal pronouns into prepositional pronouns that inflect for person and number.
} 
Word order pattern b: $\left[\mathrm{V}\right.$ NP $\left.^{\mathrm{A}} \mathrm{NP}^{\mathrm{T}} \mathbf{P P N}^{\mathrm{R}}\right] \rightarrow \mathrm{A}-\mathrm{T}-\mathrm{R}$

(10)

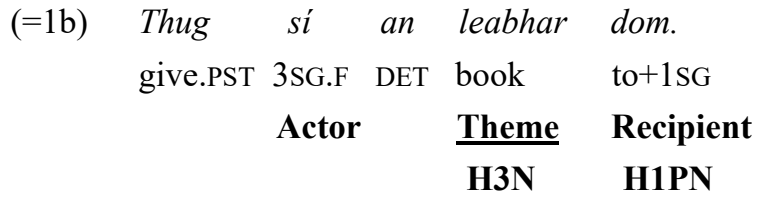

'She gave the book to me.'

A very interesting example is found in (11), where the $\mathrm{T}$ is realised as a 2 SG PN and the R is a morphologically heavier PPN, reflecting the syntactic pattern of $\left[\mathrm{V} \mathrm{NP}{ }^{\mathrm{A}} \mathrm{PN}^{\mathrm{T}} \mathrm{PPN}^{\mathrm{R}}\right]$.

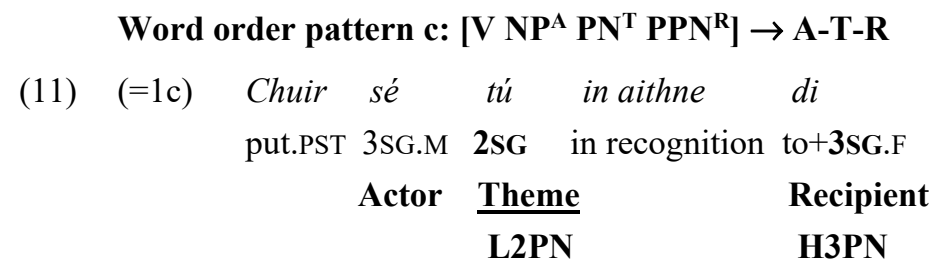

'He introduced you to her.'

In this example, we encounter some additional person hierarchy effects that influence the word order. Both the T and R contain PNs, and, as such, are equally placed on the nominal hierarchy. However, in this instance, the person hierarchy [FIRST $>$ SECOND $>$ THIRD] influences the word order of A-T$\mathrm{R}$, where the $2 \mathrm{SG}$ is more prominent that the recipient reflecting $2 \mathrm{SG}>3 \mathrm{SG}$. On the person hierarchy, the $\mathrm{T}$ is $2 \mathrm{SG}$ and the $\mathrm{R}$ is encoded in a PPN as 3 SG.F. This makes the pronominal $\mathrm{T}$ more prominent on the person hierarchy scale. What is decisive for the word order here is that, relatively, the recipient PPN is heavier and more complex than the T 2.PN, yielding A-TPN ${ }^{\text {LIGHT }}$ $\mathrm{R}_{\text {PPN }}{ }^{\text {HEAVY }}$. The facts here are that the $\mathrm{R}$ is heavier than $\mathrm{T}$, the $\mathrm{T}$ is light and a 2.PN while the $\mathrm{R}$ is a heavy 3.PN that is realised as a 3.PPN.

So far with the examinations of the three-argument construction, we have found that when the $\mathrm{R}$ is flagged by an adposition, as we commonly find in the Irish situation, the T-R order is found to be the overwhelmingly dominant order in constructions.

The marked constructions, with A-R-T word order, are examined next. We provide an example in (12) of the syntactic pattern of occurrence of $\left[\mathrm{V} \mathrm{NP}{ }^{\mathbf{A}}[\mathrm{P} \mathrm{NP}]^{\mathrm{R}} \mathrm{PN}^{\mathrm{T}}\right]$. Here, the $\mathrm{T}$ is $3 . \mathrm{PN}$ while the recipient is a full nominal within a prepositional phrase (do:P 'to' NP). We notice something very interesting with the word order of the three-argument construction 
when the $\mathrm{T}$, and syntactic direct object, is a 3.PN rather than a full nominal. The 3.PN T is realised in clause final position, after the R. In this example, A-R-T is the marked construction.

In (12), the nominal and person hierarchies influence the word order. On the nominal hierarchy, the PRONOUN is more prominent $(>)$ than the PROPER NOUN which is in turn is more prominent $(>)$ than the COMMON NOUN. The person hierarchy reflects FIRST PERSON $>$ SECOND $>$ THIRD. The 3.PN T is given and clause final, whereas the $\mathrm{R}$ is a full lexical $\mathrm{N}$ and heavier than the $\mathrm{T}$. $\mathrm{R}$ is 3rd person. With the pattern of $\mathbf{A}-\mathbf{R}_{\mathbf{N P}}{ }^{\text {HEAVY }}-\mathbf{T}_{\mathbf{P N}}{ }^{\text {LIGHT}}$, this example has a syntactic light end weight where the $\mathrm{T}$ is a light, clause final 3.PN. The $\mathrm{R}$ [+ANIM, +HUM] is more prominent than the T [-ANIM, $-\mathrm{HUM}]$ on the thematic hierarchy.

\section{Word order pattern d: [V NP $\left.{ }^{\mathrm{A}}[\mathbf{P ~ N P}]^{\mathrm{R}} \mathbf{P N}^{\mathrm{T}}\right] \rightarrow \mathrm{A}-\mathrm{R}-\mathbf{T}$}

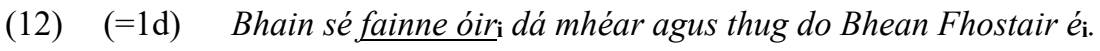

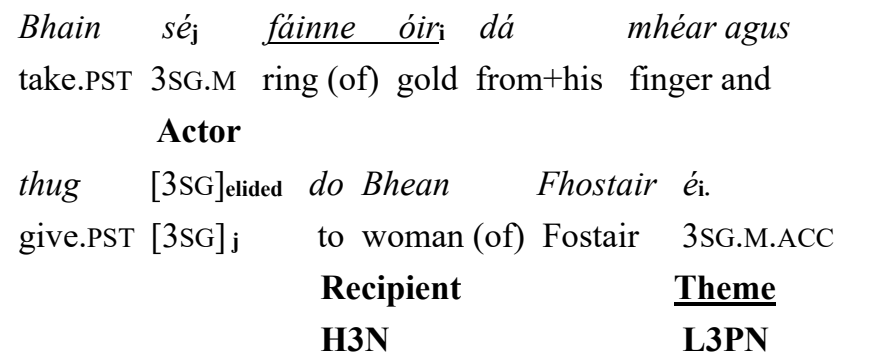

'He took a ring of gold from his finger and gave it to Foster's wife.'

We provide examples in (13) and (14) of the syntactic pattern [V NPA $\mathrm{PPN}^{\mathrm{R}}$ $\mathrm{PN}^{\mathrm{T}}$ ]. In these examples, the $\mathrm{R}$ is encoded as a PPN [dom: to $\left.+1 \mathrm{SG}=>\mathrm{PPN}\right]$. In this particular construction, the syntactic weight of the 3.PN T is light, in that the $\mathrm{T}$ consists of a single syllable word and therefore lighter than the recipient constituent, the PPN. This example with A-R-T is a marked construction, with the pattern of $\mathbf{A}-\mathbf{R}_{\mathbf{P P N}}{ }^{\text {HEAVY }}-\mathbf{T}_{\mathbf{P N}}{ }^{\text {LIGHT}}$. The $\mathrm{R}$ is encoded in a PPN as a 1.PN (that may be in fact be realised as a $1 \mathrm{st}$, $2 \mathrm{nd}$, or $3 \mathrm{rd}$ person $\mathrm{PN}$ - see example (14)). Therefore, the $\mathrm{R}$ is relatively more prominent than the $\mathrm{T}$ on the nominal and person hierarchies. The 3.PN $\mathrm{T}$ is clause final. 
(13)

\begin{tabular}{|c|c|c|c|c|}
\hline \multicolumn{5}{|c|}{ Word order pattern e: $\left[\mathrm{V} \mathbf{N P}^{\mathrm{A}} \mathbf{P P N}^{\mathrm{R}} \mathbf{P N}^{\mathrm{T}}\right] \rightarrow \mathrm{A}-\mathrm{R}-$} \\
\hline (1e) & Thug & Lorcán & dom & $\dot{e}$ \\
\hline & give.PST & Lorcan & to $+1 \mathrm{SG}$ & 3SG.M.ACC \\
\hline & & Actor & $\begin{array}{l}\text { Recipient } \\
\text { H1PN }\end{array}$ & $\frac{\text { Theme }}{\text { L3PN }}$ \\
\hline
\end{tabular}

LIT: 'Lorcan gave to me it' 'Lorcan gave it to me.'

$$
\begin{array}{llll}
\text { Thug } & \text { mé } & \text { dóibh } & \text { iad } \\
\text { give.PST } & \text { 1SG } & \text { to }+3 \mathrm{PL} & \text { 3PL.ACC } \\
& \text { Actor } & \text { Recipient } & \underline{\text { Theme }} \\
& & \text { H3PN } & \text { L3PN }
\end{array}
$$

'I gave them to them.'

However, what is decisive here for the word order is that when the $\mathrm{T}$ is a PN and the R is also a PN, then the PN T is clause final, because of the mediating influences of the nominal and person hierarchies. We can see this clearly when we contrast this with example (11), where the word order is A-T-R with the $\mathrm{T}$ a $\mathrm{L} 2 \mathrm{PN}$ and the $\mathrm{R}$ a H3PN.

Examples (13) and (14) have a heavier $\mathrm{R}$ in contrast to the lighter T. In both examples, the $\mathrm{T}$ is light, 3.PN, and the $\mathrm{R}$ is a heavy PPN with an embedded PN (that may indeed be 1st, 2nd, or 3rd person). We can note that it is not possible to assume that the animacy hierarchy might be at play here, as both the $\mathrm{T}$ and the $\mathrm{R}$ can be [+ANIM].

It is clear that the Irish data, as explicated here, contradicts the claim made by Heine and König (102), that "there is no single European language where heavy $\mathrm{R}$ precedes light $\mathrm{T}$... and also no language where heavy $\mathrm{T}$ precedes light R." As we have clearly seen, this does not reflect the situation found in the Irish data where we can find instances of a heavy $\mathrm{R}$ and a light $\mathrm{T}$. We have also seen that the realisation of the $T$ and $R$ in the three-argument constructions goes against the claims of the Principle of Early Immediate Constituents. Notwithstanding that, we typically expect the heavier constituent with new information to appear later in the clause, and the lighter constituent with old, given information, to appear earlier. Here, we present clear evidence that in the Irish three-argument constructions, the lightest argument, the 3.PN T, is clause final with the pattern A-R-T. The supposed marginality of a T-R word order does not reflect the situation with the Irish threeargument constructions. 
It is worth mentioning that, in our research, we have not found any examples of this phenomenon occurring with either a 1.PN or 2.PN (though Bennett et al., "Lightest to the Right" 172 do provide a single example with 1.PN ${ }^{4}$ ). In this research study we found that 3.PN T objects typically pattern in clause final position, such that they will occur after, for example, encoding of location (when it is an adjunct and not an argument), and adverbials of time or manner (15-16). That is, the 3.PN T object is right post-positioned as clause final and presents with the syntactic pattern of $\left[\mathrm{VSXO}_{\mathbf{P N}}\right]$, as A-R-T.

\section{Adverbial of time}

(15)

$\begin{array}{rlll}\text { Thug mé } & \text { do Sheán } & \underline{\text { inné }} & \text { é. } \\ \text { give.PST 1SG } & \text { to Seán } & \text { yesterday } & \text { 3SG.M.ACC } \\ \text { Actor } & \text { Recipient } & \underline{\text { Theme }}\end{array}$

'I gave it to Seán yesterday.'

Location as adjunct

(16)

$\begin{array}{rllcl}\text { Thug sé } & \text { leis } & \text { go dti an Ghrianán } & i \\ \text { give.PST } & \text { 3SG.M } & \text { with+3SG.M } & \text { to until DET Grianán } & \text { 3SG.F.ACC } \\ \text { Actor } & \text { Possessor } & \text { Location } & \text { Theme }\end{array}$

'He brought it with him to Grianán.'

However, a counter example (17) to this clause final positioning has been noted in the literature (Bennett et al., "Lightest to the Right," "Pronouns").

\footnotetext{
${ }^{4}$ Bennett et al. ("Lightest to the Right" 172) provide an example of a postponed 1.PN.ACC T:

(a) Chroch Stiofán agus Neili leo abhaile go dti a dteach féin mé

lift.PST Steven and Nelly with.them home to their POSS house RFX 1SG.ACC

$\begin{array}{lll}\text { Actor } & \text { Location } & \text { Possessor } \\ \text { H3N } & & \text { Theme }\end{array}$

ar an tráthnóna úd.

on the afternoon DEM

Adv.time

'Steven and Nelly carried me off home to their own house that afternoon.'
}

It may be the case that this clause final position has become conventionalised within the grammar, from usage, following from the systematic behaviour of the 3.PN T. 


\section{(17) D'fhuadaigh sé leis

$\begin{array}{rllll}\text { kidnap.PST } & \text { 3SG.M } & \text { with+3SG.M } & \text { to DET town } & \text { 3SG.F } \\ \text { Actor } & \text { Possessor } & \text { Location } & \text { Theme Adv.manner }\end{array}$

'Secretly, he (forcibly) took her with him to the town.'

In this counterexample, with the clause containing both an adjunct of location and adverb of manner, the manner adverb occurs at the outer periphery of the clause and, within its wide clausal scope, has the full event denoted by the verb and its arguments within the clausal core. The expression of location is as an adjunct, not an argument. The scope of the location adjunct is the clausal CORE, not the clause itself. Clause structure in RRG is captured in a semantically-based model known as the "layered structure of the clause." The essential components of this model of the clause are (i) the NUCLEUS, which contains the predicate, (ii) the CORE, which contains the nucleus plus the arguments of the predicate in the nucleus, and (iii) a PERIPHERY for each clausal layer, which contains adjunct modifiers, including that of location. Note that in the thematic hierarchy, location, as an argument, and recipient have equal prominence. In Irish, the recipient argument is encoded as the object of a preposition.

\section{CONCLUDING DISCUSSION}

We have noted the syntactic patterns, repeated here from earlier as (18), of the word order alignment found with the three-argument constructions and provided examples, with discussion and analysis, for each of these patterns. We found that it is normal and productive to have word orders of A-T-R and A-R-T, and we found this phenomenon occurs in all mediums of Irish, spoken, written, and online communications such as internet memes (figure 1).

(18) The patterns of occurrence of the three-argument construction of Irish
a. $\quad\left[V N P^{A} N P^{\mathrm{T}}[P N P]^{\mathrm{R}}\right] \quad$ : $\quad$ A-T-R
b. $\left[V N^{A} N^{\mathrm{T}} P P N^{R}\right] \quad$ : $A-T-R$
c. $\left[V N^{A} P^{\mathrm{T}} P P N^{\mathrm{R}}\right] \quad$ : $\mathrm{A}-\mathrm{T}-\mathrm{R}$
d. $\quad\left[\mathrm{V} \mathrm{NP}{ }^{\mathrm{A}}[\mathrm{P} \mathrm{NP}]^{\mathrm{R}}\right.$ 3.PN $\left.{ }^{\mathrm{T}}\right] \quad$ : $\quad$ A-R-T marked form of construction
e. $\left[\mathrm{V} \mathrm{NP}^{\mathrm{A}} \mathrm{PPN}^{\mathrm{R}}\right.$ 3.PN $\left.\mathbf{P N}^{\mathrm{T}}\right] \quad$ : $\quad$ A-R-T marked form of construction 


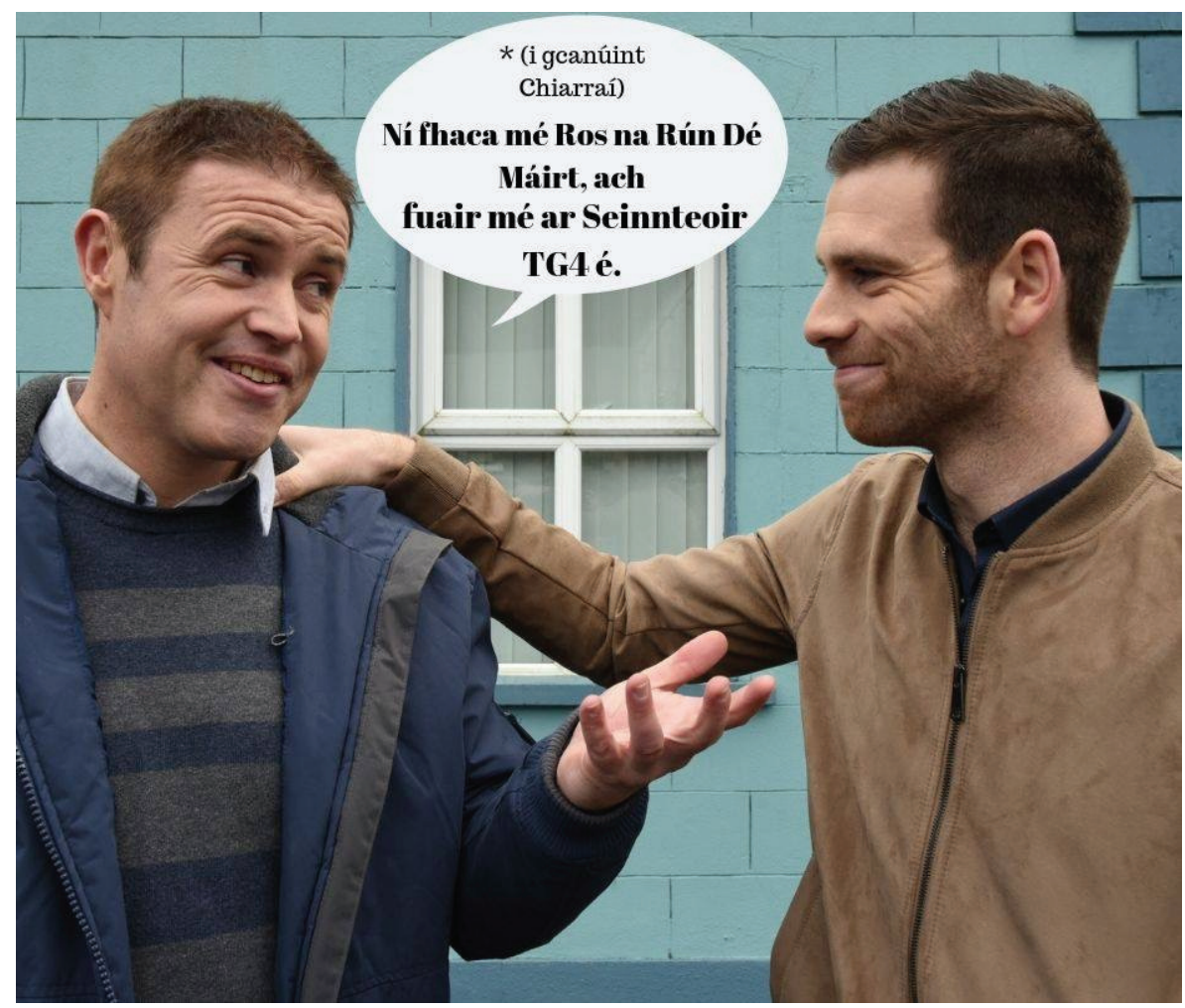

Figure 1. Meme promoting TG4 TV player using a three-argument construction (May 2019). Available at www.facebook.com/RosnaRun/photos/b\%C3\%AD-ar-nós-david-má-chaill-sibh-ros-narún-an-tseachtain-seo-tá-sé-le-fáil-ar-sei/2210219819098149. Accessed 9 June 2021.

We initially claimed that:

a) T-R marginality does not reflect the situation with the Irish threeargument constructions, as evidenced by the data in (1) and the occurrence patterns repeated in (18).

b) When the $\mathrm{R}$ is flagged by an adposition, as in Irish, the T-R order is found to be the overwhelmingly dominant order in constructions.

c) The nominal and person hierarchies come into play with respect to Irish three-argument constructions.

d) The statement that "there is no single European language where heavy $\mathrm{R}$ precedes light $\mathrm{T} \ldots$ and also no language where heavy $\mathrm{T}$ precedes light $\mathrm{R}$ " (Heine and König 102) does not reflect the situation found with the Irish data where we find a heavy $\mathrm{R}$ and a light $\mathrm{T}$. 
e) The realisation of the $T$ and $R$ of the three-argument constructions goes against the claims of the Principle of Early Immediate Constituents. In Irish three-argument constructions, the lightest argument, the 3.PN T, is clause final with the pattern A-R-T.

In this study, we supported these claims through discussion of the relevant data, and have found that:

i. The Irish grammar favours the clause final placement of the 3.PN.ACC $\mathrm{T}$ object, and that the nominal and person hierarchies, in their interaction with the syntactic weight of the $\mathrm{T}$ and $\mathrm{R}$ constituents, has a constraining influence on the word order realisation in the Irish grammar (Siewierska, "Syntactic Weight," "Word Order," "Person Agreement," Person; Haspelmath, "Argument Marking," "Ditransitive Constructions"; Hawkins, Performance Theory, "Some Issues," Efficiency). Once the T occurs as a 3.PN.ACC object, it is then clause final in a marked construction.

ii. Irish grammar will attempt to place the heaviest constituent elements last in the clause, giving A-T-R, except where the T is a 3.PN.ACC, in which case the 3.PN.ACC $\mathrm{T}$ is rightmost as the nominal and person hierarchies cause the word order alignment to become A-R-T, while factoring in syntactic weight.

iii. Typically, it seems that the most frequent occurrence of this postposing phenomenon is with a 3.PN. The 3.PN.ACC is realised in accusative form and semantically has PATIENT or UNDERGOER qualities. With the sole example of 1.PN provided by Bennett et al. ("Lightest to the Right" 172), we have not managed to find examples of this phenomenon occurring with a 1PN.ACC, or 2.PN.ACC.

iv. The Irish postposing phenomenon contradicts Hawkins' (Hawkins, Performance Theory, "Some Issues," Efficiency; Tallerman, "Word Order," "Celtic Word Order") Principle of Early Immediate Constituents, under which the preferred word order is one in which the constituents are recognised as early as possible in such a way that facilitates constituent recognition and ease of processing.

v. For Irish, this postposing phenomenon runs counter to the general tendency for given elements, such as pronouns, to occur early within the clause. The clause final 3.PN.ACC T contains given information and this goes against the expectation that given information will always be clause initial.

vi. The phenomenon gives an imposed salience or prominence to the 3.PN.ACC T object (the PATIENT or UNDERGOER) such that this salience casts an added emphasis on the $\mathrm{T}$ in this circumstance within the A-R-T marked construction. 
vii. Claims that the linear order of ditransitive objects in European languages can be explained with reference solely to the thematic and the case hierarchies (Primus 424) are revealed to not reflect the situation found in Irish, where the nominal and person hierarchies, syntactic weight, and thematic hierarchy, are significant.

These word alignment effects with the clause final 3.PN.ACC T, and their motivations as argued for here, raise important questions of the distribution of linguistic complexity across the grammar of Irish, and the interfaces between semantics, and syntax, as well as information structure. What may look like free syntactic variation with argument realisation actually reflects a subtle and productive constraint that is not a matter of a speaker's stylistic choice.

\section{WORKS CITED}

Bennett, Ryan, et al. "Pronouns and Prosody in Irish." Proceedings of the XIV International Congress of Celtic Studies, Maynooth University, 1-5 August 2011, edited by Liam Breatnach et al., School of Celtic Studies, Dublin Institute for Advanced Studies, 2015, pp. 19-74.

Bennett, Ryan, et al. "Lightest to the Right: An Apparently Anomalous Displacement in Irish." Linguistic Inquiry, vol. 47, no. 2, 2016, pp. 169-234. doi.org/10.1162/LING_a_00209.

Birner, Betty J. "Information Status and Word Order: An Analysis of English Inversion." Language, vol. 70, 1994, pp. 233-259.

Birner, Betty J., and Gregory Ward. Information Status and Non-Canonical Word Order in English. John Benjamins Publishing Company, 1998.

Brown, Cheryl. "Topic Continuity in Written English Narrative.” Topic Continuity in Discourse. A Quantitative Cross-Language Study, Typological Studies in Language 3, edited by Givón Talmy, John Benjamins Publishing Company, 1983, pp. 315-341.

Butler, Christopher S. Structure and Function: A Guide to Three Major Structural Functional Theories. Part 2, John Benjamins Publishing Company, 2003.

Croft, William. Typology and Universals. Cambridge UP, 1990.

Falk, Yehuda. Subjects and Universal Grammar. Cambridge UP, 2006.

Haspelmath, Martin. “Argument Marking in Ditransitive Alignment Types.” Linguistic Discovery, vol. 3, 2005. linguistic-discovery.dartmouth.edu. Accessed 8 Jan. 2020.

Haspelmath, Martin. "Ditransitive Constructions: The Verb 'Give'." The World Atlas of Language Structures, edited by Martin Haspelmath et al., Oxford UP, 2005, pp. 426-429.

Hawkins, John A. A Performance Theory of Order and Constituency. Cambridge UP, 1994. Cambridge Studies in Linguistics 73.

Hawkins, John A. "Some Issues in a Performance Theory of Word Order." Constituent Order in the Languages of Europe, edited by Anna Siewierska. Mouton de Gruyter, 1998, pp. 729-782. Empirical Approaches to Language Typology 20.

Hawkins, John A. Efficiency and Complexity in Grammars. Oxford UP, 2004. 
Heine, Bernd, and Christa König. "On the Linear Order of Ditransitive Objects." Language Sciences, vol. 32, 2010, pp. 87-131. www.researchgate.net/publication/223187020_On_the linear_order_of_ditransitive_objects. Accessed 8 June 2020.

Hickey, Raymond. Irish-English: History and Present Day Forms, Studies in English Language. Cambridge UP, 2008.

Levin, Beth, and Malka Rappaport Hovav. Argument Realization. Cambridge UP.

Malchukov, Andrej, et al. Ditransitive Constructions: A Typological Overview. www.researchgate.net/ publication/265423193_Ditransitive_constructions_A_typological_overview, 2007. Accessed 9 June 2020

Malchukov, Andrej, et al. Studies in Ditransitive Constructions: A Comparative Handbook. Walter de Gruyter, 2010.

Mallinson, Graham, and Barry Blake. Language Typology: Cross-Linguistic Studies in Syntax. North Holland, 1981.

Mulkern, Ann Elizabeth. "Left Right Behind: Irish Pronoun Postposing and Information Structure." Formal Approaches to Celtic Linguistics, edited by Andrew Carnie, Cambridge Scholars Publishing, 2011, pp. 179-202.

Nolan, Brian. The Structure of Modern Irish: A Functional Account, Discussions in Functional Approaches to Language. Equinox Publishing Company, 2012.

Ó Siadhail, Mícheál. Modern Irish. Cambridge UP, 1989 [1991].

Payne, Doris. L. The Pragmatics of Word Order: Typological Dimensions of Verb-Initial Languages, Mouton de Gruyter, 1990. Empirical Approaches to Language Typology 7.

Payne, Doris. L., editor. Pragmatics of Word Order Flexibility, Typological Studies in Language 22. John Benjamins Publishing Company, 1992.

Payne, Doris. L. "Verb Initial Languages and Information Order." Word Order in Discourse, edited by Pamela Downing and Michael Noonan, John Benjamins Publishing Company, 1995, pp. 449-486. Typological Studies in Language 30.

Primus, Beatrice. "The Relative Order of Recipient and Patient in the Languages of Europe." Constituent Order in the Languages of Europe, edited by Anna Siewierska, Mouton de Gruyter, 1997, pp. 421-473. Empirical Approaches to Language Typology 21-1.

Ruhlen, Merritt. A Guide to the Languages of the World. Stanford UP, 1975. Language Universals Project.

Siewierska, Anna. "Syntactic Weight vs. Information Structure and Word Order Variation in Polish.” Journal of Linguistics, vol. 29, no. 2, 1993, pp. 233-265. www.jstor.org/stable/4176234. Accessed 8 Jan. 2020.

Siewierska, Anna. "Word Order and Linearization." The Encyclopedia of Language and Linguistics. 2nd ed., edited by Keith Brown, Pergamon and Aberdeen UP, 1994, pp. 642-649.

Siewierska, Anna, editor. Constituent Order in the Languages of Europe, Mouton de Gruyter, 1998. Empirical Approaches to Language Typology 21-1.

Siewierska, Anna. "Person Agreement and the Determination of Alignment." Transactions of the Philological Society, vol. 101, no. 2, 2003, pp. 339-370.

Siewierska, Anna. Person. Cambridge UP, 2004 
Silverstein, Michael. "Hierarchy of Features and Ergativity." Grammatical Categories in Australian Languages, edited by Robert M. W. Dixon, Australian Institute of Aboriginal Studies, 1976, pp. 112-171.

Stefanowitsch, Anatol, and Stefan Th. Gries. "Givenness and Linear Precedence: A ConstructionGrammar Approach." Paper given at the 2nd International Construction Grammar Conference (ICCG 2), Helsinki, Finland. 6-8 Sept. 2002.

Tallerman, Maggie. "Word Order in Celtic." Constituent Word Order in the Languages of Europe, edited by Anna Siewierska, Mouton de Gruyter, 1998, pp. 21-46. Empirical Approaches to Language Typology 21-1.

Tallerman, Maggie. "Celtic Word Order: Some Theoretical Issues." Constituent Word Order in the Languages of Europe, edited by Anna Siewierska, Mouton de Gruyter, 1998, pp. 599-648. Empirical Approaches to Language Typology 21-1.

Van Valin, Robert. Exploring the Syntax-Semantics-Pragmatics Interface. Cambridge UP, 2005.

Van Valin, Robert. "Role and Reference Grammar as a Framework of Linguistic Analysis." The Oxford Handbook of Linguistic Analysis, edited by Bernd Heine and Heiko Narrog, Oxford UP, 2010, pp. 703-738.

Van Valin, Robert, and Randy LaPolla. Syntax. Cambridge UP, 1997.

\section{UPORZĄDKOWANIE LINEARNE W STRUKTURACH TRÓJMIEJSCOWYCH W JĘZYKU IRLANDZKIM}

\section{Streszczenie}

W artykule zbadano uporządkowanie linearne aktantów aktor (A), temat (T) oraz odbiorca (R) w predykatach trójmiejscowych w języku irlandzkim w oparciu o założenia modelu Role and Reference Grammar. Istnieje szereg czynników, które wpływają na przekład związków semantyczno-syntaktycznych na podstawowy szyk zdaniowy A-T-R. Należą do nich ikoniczność, struktura informacyjna, topikalizacja, rozróżnienie pomiędzy informacją podaną a nową, wpływ różnych hierarchii referencyjnych oraz znaczenie syntaktyczne. Wykazano, że niektóre z nich mają zastosowanie dla danych z języka irlandzkiego. Jeśli temat ma formę zaimka w bierniku, szyk ulega zmianie i w konsekwencji temat występuje po odbiorcy na końcu zdania prowadząc do uporządkowania A-R-T. Postpozycja tematu mającego formę zaimkową wynika $\mathrm{z}$ wzajemnych oddziaływań pomiędzy hierarchią rzeczownikową i zaimkową a zasadą wagi syntaktycznej. $\mathrm{W}$ gramatyce irlandzkiej istnieje tendencja do umieszczania biernikowego tematu na końcu zdania przy jednoczesnym dodaniu narzuconej niezmienności.

\section{Przektad angielskiego abstraktu} Maria Bloch-Trojnar

Słowa kluczowe: czasownik przechodni podwójnie (ditransitivum); język irlandzki; szyk zdaniowy; hierarchie rzeczownikowe i zaimkowe; waga syntaktyczna; postpozycja tematu. 